\title{
THE IMPACT OF DESTINATION IMAGE ON REVISIT INTENTION MEDIATION ROLE BY OVERALL SATISFACTION PERSPECTIVE FROM SHOPPING DESTINATION IN BANDUNG, INDONESIA
}

\author{
Bob Foster ${ }^{1}$, Iwan Sidharta ${ }^{2}$ \\ 1 Universitas Informatika dan Bisnis Indonesia, Bandung, Indonesia \\ 2Sekolah Tinggi Ilmu Ekonomi, Pasundan, Bandung, Indonesia. \\ E-mail: foster.unibi@gmail.com¹, iw.sidh@gmail.com²
}

\begin{abstract}
Currently, the tourism sector is a central issue in the growth of a country. Researchers have proven the critical role of the tourism sector in increasing state revenues through tourist visits, both domestic and foreign tourists. Several previous studies have shown the part of the destination image in increasing the revisit rates. However, multiple research models have differed variations in explaining the influence of the destination image on the tourists' loyalty to revisit shopping destinations. Therefore, this study aims to determine the effect of destination image on tourist revisit intention towards shopping tours in Bandung. The survey approach is used to answer the research objectives. The results prove there is an influence of the destination image on the tourists' revisit intention to shopping tours with 179 samples carried out simultaneously on several shopping tourist destinations in Bandung. Thus, the proper advice to improve the revisit intention is providing facilities and infrastructure as well as exciting experiences for the tourists.
\end{abstract}

Keywords: shopping tourism, destination image, revisit intention, overall satisfaction.

\section{INTRODUCTION}

In general, tourism activities cannot be separated from the elements of shopping, good food (Wijaya, King, Morrison \& Nguyen, 2017) and the other needs during the vacation and the souvenirs as gifts. (Kong \& Chang, 2012) These factors can be used as the main attraction of a tourist destination for the shopping tourism that is developed in a holistic tourism industry concept. (Kong \& Chang, 2016) Recently, tourist destinations already have various shopping centers to fulfill the tourists' needs during their vacation. However, these shopping centers do not have an integrated shopping tourism concept that turns into 
a holistic tourism industry concept. (Swanson \& Horridge, 2006; LeHew \& Wesley, 2007; Altintzoglou, Heide \& Borch, 2016)

Shopping tourism is a tourist concept with a special attraction for tourists. (McKercher \& Wong, 2004; Makkonen, 2016) Unlike the nature tourism concept and cultural tourism, the shopping tourism concept can be created in a relatively shorter time. In principle, shopping tourism is an activity or trip carried out by a person or group of people in their activities related to the purchase of goods or services at a tourist destination. (Altintzoglou, Heide \& Borch, 2016) Shopping tourism is an interesting experience for tourists who think that shopping is one of the fun activities and can consider as a recreational activity that aims to entertain them during the vacation. (Lin \& Mao, 2015) Shopping tourism is not only for fulfilling their needs while visiting the tourist destination but also for satisfying their desires. (Tosun, Temizkan, Timothy \& Fyall, 2007) As a way to satisfy these desires, sometimes the tourists do not calculate the amount of money or sacrifice compared to the value of the goods or services. (Lehto, Cai, O'Leary \& Huan, 2004)

Visitor satisfaction is a central concept in tourism and marketing (Petrick, 2004; Chen \& Tsai, 2007). In general, satisfaction is the extent to which someone believes that experience provides positive feelings for his/her expertise in consumer products or services. In a tourism perspective, satisfaction is an evaluation of the knowledge that should be felt (Hunt, 1983). Therefore, it is relevant if the experience of tourists in feeling satisfaction is following their expectations (Lee et al., 2005). This satisfaction has reviewed by previous researchers (Cronin \& Taylor, 1992). For this reason, measuring satisfaction is essential in determining the tourists' future behavior. Some studies measure tourist satisfaction by summarizing traveler evaluations of tourist destination attributes (Kozak, 2003; Um, Chon, \& Ro, 2006). Overall satisfaction is an accumulation of tourist experience (Andreassen, 1995; Fornell, 1992). Concerning loyalty, relationships with tourists are built based on tourist loyalty in the context of tourism. Tourists have confidence in the received value, leading to their overall attitude towards the destination of tourism, which has implications for the revisit intention. Previous research has discussed a destination image with revisit intention (Chen and Phou, 2013; Huang and Hsu, 2010; Mechinda, Serirat \& Gulid, 2009; Ramkissoon, Uysal \& Brown, 2011). The received experience by tourists in visiting (Allameh et al., 2015) sport destinations (Hallmann, Zehrer \& Müller, 2015), to city destinations (Kim \& Lee, 2015; Tosun, Dedeoğlu \& Fyall, 2015; Prayag et al., 2017), island destination (Ramseook-Munhurrun, Seebaluck \& Naidoo, 2015), urban tourist (Papadimitriou, Apostolopoulou and Kaplanidou, 2015), selecting on destination (Stylos et al., 2016; Stylos et al., 2017), quality of tourist shuttles (Loi et al., 2017). Furthermore, several studies have shown that overall satisfaction affects revisit Intention (Chi \& Qu, 2008; Ryu et al., 2008; Prayag, 2009).

The study stated that the importance of evaluating satisfaction in determining the behavior of tourists to revisit tourist destinations and the image of a tourist destination has some implications for the revisit intention. Therefore, this research contributes in bridging the gap of previous research by modeling the destination image of the revisit intention, 
which is mediated by overall satisfaction, The results of the study will show both direct and indirect effect. The difference approach, found in previous studies, requires further exploratory research that is more appropriate to be applied to tourism shopping conditions in Bandung, Indonesia. Therefore, this study aims to determine the extent of the influence of destination image on revisit intention, which is mediated by overall satisfaction with the object of shopping tourism research in Bandung, Indonesia.

\section{CONCEPTUAL FRAMEWORK AND HYPOTHESES}

Satisfaction is the expectation of the consumed product or service. In the context of the destination image, satisfaction relates to the contribution of tourist expectations based on the experience of the destination image (Chi \& $\mathrm{Qu}, 2008$ ). The rule from overall satisfaction is visible from the global level, attribute level (Oliver, 1993), which is a function of attribute level evaluation (Bolton \& Drew, 1991). Overall satisfaction in the tourist constituents is the perceived satisfaction with the inherited attributes in the destination (Hui, Wan \& Ho, 2007; Alegre \& Garau, 2010). Tourist satisfaction is highly dependent on the attributes of a destination image (Prayag, 2009; Wang \& Hsu, 2010; Chen \& Phou, 2013). Attribute from destination image greatly influences tourism behavior so that the attributes attached to the destination image must be presented interestingly (Stylos et al., 2016). The attractive destination image attribute (Chen, Chen $\&$ Lee, 2010) provide Overall Satisfaction for tourists (Chen \& Myagmarsuren, 2010).

Revisit Intention can be seen from the tourists' desire to revisit (Wang \& Hsu, 2013) destination image which is one strategy to evaluate the success of tourism destination (Alexandris, Kouthouris \& Meligdis, 2006). Some studies have shown a close relationship between destination image and revisit intention (Um, Chon \& Ro 2006) but there is no consensus regarding the type of connection (Morais \& Lin, 2010; Cheng \& Lu, 2013; Josiassen, Assaf, Woo \& Kock, 2016; Lee, 2009). The destination image can influence the consumers' behavior in revisit the destinations (Chen \& Tsai, 2007;), emotions and switching barriers (Han, Back \& Barrett, 2009), perceived attractiveness and overall satisfaction (Um, Chon \& Ro, 2006), quality and value (Quintal \&and Polczynski, 2010), motives of tourist (Li et al., 2010), relaxation and recreation (Som et al., 2012), self-congruity (Zhang et al., (2014) and some matters which are related to cognitive and affective from destination (del Bosque and Martín, 2008; Hallmann and Breuer, 2010; Wang, Wu and Yuan, 2010). Research conducted by Chen \& Tsai (2007); Hallmann, Zehrer and Müller (2015); Stylos et al., (2016); Stylos et al., (2017) prove there are several influences of destination image significant influences in the Revisit Intention. Likewise, research conducted by Assaker, Vinzi and O'Connor (2011); Lee, Lee \& Lee (2014); and Prayag et al., (2017) prove that destination image is significantly influential in the overall satisfaction. Further research conducted by Chen \& Chen (2010) 
and Žabkar, Brenčič \& Dmitrović (2010) justify that overall satisfaction mediates the destination image and the revisit intention.

According to the framework above, the hypothesis in this study are:

H1. The destination image significantly affects the revisit intention

$\mathrm{H} 2$. The destination image substantially affects the overall satisfaction

H3. Overall satisfaction significant affect the revisit intention

\section{METHOD}

Predictive modeling used in the development of research models to do the more profound exploration of the variables that form the destination image. The variables are lodging facility, quality of food, and relaxation experience. Then, the destination image variable that has been constructed from these components is measured in terms of the perception of revisit intention and the other influences by using mediation by the overall satisfaction variable. The measurements of all effect were carried out through a variance based Structural Equation Model (SEM) data analysis technique. It is by testing the research hypothesis of a non-parametric approach using Partial Least Square (PLS) with PLS 3.0 Warp. The use of PLS is considered more appropriate for non-parametric measurements, for predicting the influence between constructs and the relationship of indicators that are reflective and formative. Besides, the trend in analyzing the similar model of business research is by using PLS

The study employs the sampling method due to the sizeable population. The sampling technique is carried out by using a non-probability sampling method. The sample in the population chosen because the chance factors are used as representative samples.

Bandung is the fourth largest city in Indonesia, which has become one of the main tourist destinations in Indonesia. Bandung has a unique attraction for tourists from various regions. Bandung, as a tourist city has various tourist destinations related to nature, history, and culture. Moreover, tourists often visit Bandung for shopping. The fulfillment of all the tourists' needs and desires during their visit to a tourist destination lead to tourists' satisfaction that will affect the tourists revisit intention.

Furthermore, the sampling technique is accidental sampling. It is based on the spontaneous factor of tourists who were accidentally met while collecting the representative data on the characteristics of the entire population. Besides, the samples were cooperative to be the object of research. In total, 225 questionnaires were distributed to several major shopping tourist destinations in Bandung with proportionality previously reviewed. A total of 203 samples were obtained during the data collecting process, but only 179 samples were valid for further study.

In measuring the Destination Image, the first step is assessing its constituent components: the lodging facility with five items of instruments, quality of food with four elements of instruments and relaxation experiences with six items of instruments - the measurement of the overall satisfaction variable done through 5 instrument items. The 
instrument is adopted from Kozak \& Rimmington, 2000; Chi \& Qu, 2008; Qu, Kim \& Im, 2011; Wang \&and Hsu, 2010 which was validated by Foster (2018) and Revisit Intention was carried out through 5 instrument items by adopting the TPB approach (Ajzen, 1988). All research instruments are calculated by using a Likert scale with five scale measurement perceptions.

The research instrument in this study and the results of validity test as show at table.

Table 1. Research Instument and Outer Loading Indicator Validity

\begin{tabular}{|l|l|l|l|l|l|}
\hline Indicator & Lodging & $\begin{array}{l}\text { Qualit } \\
\mathrm{y}\end{array}$ & Relax & Revisit & Satisfaction \\
\hline Lo_1 & 0.716 & & & & \\
\hline Lo_2 & 0.844 & & & & \\
\hline Lo_3 & 0.815 & & & & \\
\hline Lo_4 & 0.853 & & & & \\
\hline Lo_5 & 0.742 & & & & \\
\hline Qu_1 & & 0.576 & & & \\
\hline Qu_2 & & 0.867 & & & \\
\hline Qu_3 & & 0.788 & & & \\
\hline Qu_4 & & 0.755 & & & \\
\hline Rel_1 & & & 0.531 & & \\
\hline Rel_2 & & & 0.696 & & \\
\hline Rel_3 & & & 0.656 & & \\
\hline Rel_4 & & & 0.509 & & \\
\hline Rel_5 & & & 0.753 & & \\
\hline Rel_6 & & & 0.636 & & \\
\hline Rev_1 & & & & 0.716 & \\
\hline Rev_2 & & & & 0.805 & \\
\hline Rev_3 & & & & 0.649 & \\
\hline Rev_4 & & & & 0.731 & \\
\hline Rev_5 & & & & 0.671 & \\
\hline Sat_1 & & & & & 0.836 \\
\hline Sat_2 & & & & & 0.835 \\
\hline Sat_3 & & & & & 0.773 \\
\hline Sat_4 & & & & & 0.802 \\
\hline Sat_5 & & & & & 0.684 \\
\hline
\end{tabular}

The results of the validity testing of all the indicator instruments indicate all indicators are valid to use in research, based on the testing criteria for the outer loading indicator> 0.5 as the conditions stated earlier.

The entire data obtained through the questionnaire were analyzed by a non-parametric approach by using Partial Least Square (PLS). The provisions of the data testing refer to the specified conditions as in testing validity which requires the outer loading indicator value> 0.5. The reliability testing requires a calculation value Average Variance Extracted, Cronbach's Alpha and Composite Reliability (Kock, 2012). The results of validity test listed in the table 2 . 
Table 2. Result of Average Variance Extracted (AVE), Cronbach's Alpha and Composite Reliability

\begin{tabular}{|l|c|c|c|}
\hline \multicolumn{1}{|c|}{ Variables } & AVE & $\begin{array}{c}\text { Cronbach's } \\
\text { alpha }\end{array}$ & $\begin{array}{c}\text { Composite } \\
\text { Reliability }\end{array}$ \\
\hline Lodging Facility & 0.633 & 0.854 & 0.896 \\
\hline Quality of Food & 0.568 & 0.739 & 0.838 \\
\hline Relaxation Experience & 0.504 & 0.798 & 0.900 \\
\hline Destination Image & 0.598 & 0.744 & 0.910 \\
\hline Overall Satisfaction & 0.621 & 0.846 & 0.891 \\
\hline Revisit Intention & 0.513 & 0.761 & 0.840 \\
\hline
\end{tabular}

Applying the testing requirements with the criteria outlined previously such as Average Variance Extracted (AVE) $>0.5$, Cronbach's Alpha $>0.7$ and Composite Reliability $>0.7$ (Kock, 2014), the test results show that all variables used in the research model are reliable.

All the instruments and variables are valid and reliable. Furthermore, this research is carrying out another analysis to find out the influence of the destination image variable on the revisit intention, which is mediated by the overall satisfaction variable.

\section{RESULTS AND DISCUSSION}

The calculation results of the magnitude of the influence between exogenous variables, namely destination image formed through the components of the lodging facility, quality of food and relaxation experiences on the endogenous variables, the revisit intention, are influenced by the mediator of overall satisfaction variables entirely presented in the table 3 .

Table 3. Path Coefficients Values

\begin{tabular}{|l|c|c|c|}
\hline \multicolumn{1}{|c|}{ Variables } & $\begin{array}{c}\text { Path } \\
\text { Coeficient }\end{array}$ & P Value & Descision \\
\hline Destination Image $\rightarrow$ Revisit Intention & 0.398 & 0.001 & Accept \\
\hline $\begin{array}{l}\text { Destination Image } \rightarrow \text { Overall } \\
\text { Satisfaction }\end{array}$ & 0.544 & 0.001 & Accept \\
\hline Overall Satisfaction $\rightarrow$ Revisit Intention & 0.319 & 0.001 & Accept \\
\hline
\end{tabular}

Figure 1illustrates the development of further research models based on predicted variables to form destination image such as lodging facility, quality of food and relaxation experience and adversely influencing the revisit intention with the mediator of overall satisfaction variables. 


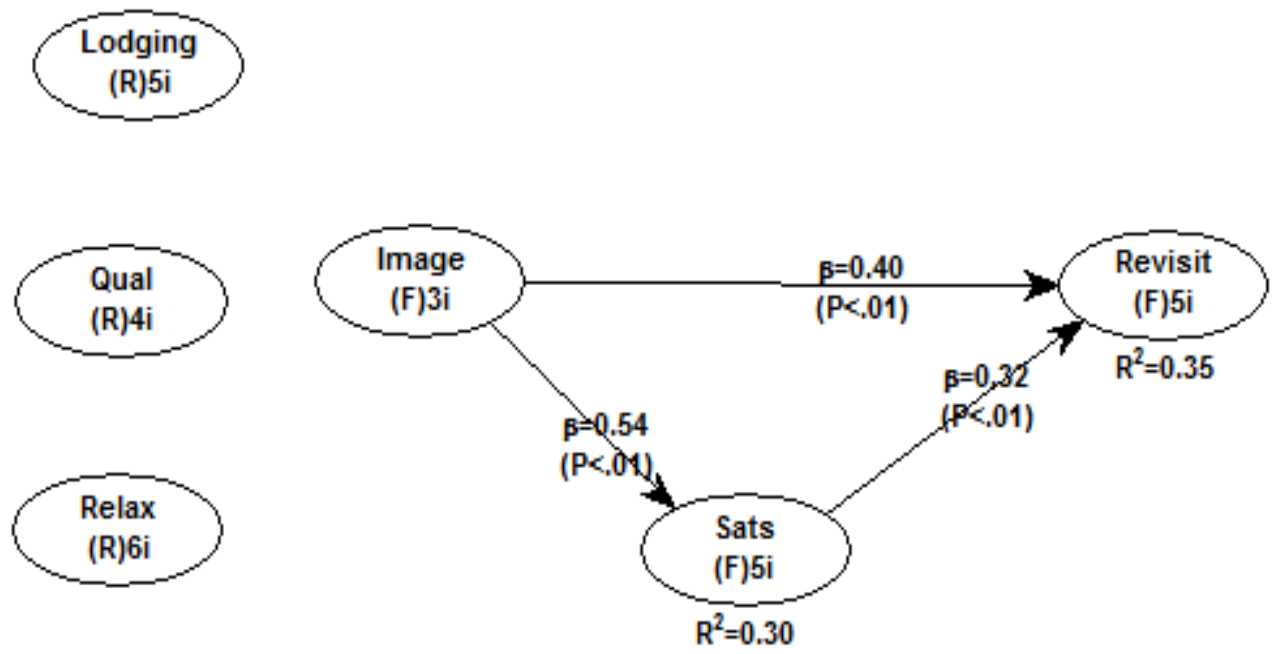

Figure 1. Destination Image on Revisit Intention and role of Overall Satisfaction

Figure 1 shows the modeling structure of the destination image forming variables, which consists of the lodging facility, quality of food, and relaxation experiences. Furthermore, the model also illustrates how much the destination image influences the revisit intention influenced by overall satisfaction as the mediator variable.

The fit model is used to test the overall research model. Value of Average Path Coefficients (APC) shows the calculation result of 0.463 and P-value of 0.001 , while the Tenenhaus Goodness of Fit $(\mathrm{GoF})$ value is 0.369 . The results of the calculation explain that the overall development of the research model used in this study is in the substantial criteria.

The development of predictive research models in this research is based on previous research that is relevant to be applied in modeling the components of the destination image. The parts are shopping tourism destinations in Bandung, which consists of some elements such as lodging facility, quality of food, and relaxation experiences. The results of the calculation of the fit model indicate that the research model is in the outstanding assessment criteria (large). The results of calculations and analyses state that the entire research instruments or indicators on the variables used in the study are valid. Furthermore, the reliability test proves that all variables used in the research are reliable.

The development of the research structure model is analyzed using path analysis. The destination image has a direct effect on revisit intention and its influence through the mediator of overall satisfaction variables. The results and interpretations of the study are as follows:

(H1) Destination Image, destination image affects the revisit intention with the path coefficient of 0.398 and p-value of 0.001 . The calculation of p-value is smaller than $5 \%$ shows that the destination image has a significant effect on revisit intention. The calculation results show that improving the destination image is essential. It supports the 
efforts of increasing tourist visits in the next period through the perception of tourists who have visited. Increased tourist perceptions of the destination image is a manifestation of continuous and comprehensive improvement of the components in this study, represented by lodging facility, quality of food, and relaxation experiences. (Chi \& Qu, 2008; CampoMartínez, Garau-Vadell \& Martínez-Ruiz, 2010; Foster, 2018) This fact has a connection with the shopping tourism in Bandung. The improvement of supporting facilities and infrastructure in shopping tourism activities increase the tourists' perceptions toward Bandung's shopping tourism destination image. Later, this condition gives an effect on the perception of revisit intention.

(H2) Destination Image, destination image affects the overall satisfaction with the path coefficient of 0.544 and p-values of 0.001 . The calculation of p-values is smaller than 5\%, which means the destination image has a significant effect on overall satisfaction. The significance of the destination image's influence on overall satisfaction illustrates that the continuous and comprehensive improvement on the entire destination image's components will increase the total satisfaction (Bianchi \& Pike, 2011; Choi, Tkachenko \&Sil, 2011; Chew \& Jahari, 2014; Hallmann, Zehrer \&and Müller, 2015; Kim \& Lee, 2015; Foster \& Sidharta, 2019) in this case is the tourists' satisfaction in making shopping tours in Bandung. After making a tourist shopping visit in Bandung with its destination image, the tourists get an exciting experience that leads to satisfaction.

(H3) Overall satisfaction, overall satisfaction has an effect on revisit intention with a path coefficient of 0.319 and a p-value of 0.001 . The calculation of p-values is smaller than 5\%. It means the overall satisfaction has a significant effect on revisit intention. In marketing management science, customer satisfaction is a common goal that must be addressed to get the primary purpose: customer loyalty. The application is similar in the strategy of developing a tourist destination. The tourists' satisfaction after their visit is the first step to get their commitment. In this case, it is actualized through the perception of revisit intention (Prayag, 2009; Stylos et al., 2016; Stylos et al., 2017; Prayag et al., 2017) the shopping tourist destinations in Bandung. A thorough study of the factors that determine the tourists' satisfaction in their visits can be future research material. It provides input as a basis of consideration for the regulators in determining the optimum strategies in developing a tourist destination.

The results of this study show that destination image plays an essential role in forming the tourists' overall satisfaction. Furthermore, it creates the tourists' revisit intention to tourist destinations. The result of the study can be used as a comparison material with previous researches done by Chew \&and Jahari, 2014; Allameh et al., 2015; RamseookMunhurrun, Seebaluck \& Naidoo, 2015; Papadimitriou, Apostolopoulou and Kaplanidou, 2015; Tosun, Dedeoğlu \& Fyall, 2015; Loi et al., 2017; which prove that destination image has a positive and significant effect on revisit intention which is mediated by overall satisfaction. (Chi \& Qu, 2008; Ryu et al., 2008). 


\section{CONCLUSION}

The results of the study concluded that the tourists' revisit intention towards shopping destinations in Bandung formed by the factor of Bandung's destination image components such as the lodging facility, quality of food and relaxation experiences. Besides being created directly by Bandung's destination image as a shopping tourist destination, the tourists' revisit tourists' overall satisfaction also influences intentions in visiting the shopping tourism destinations in Bandung after making shopping tours in Bandung with its unique destination image.

According to the results of research on shopping destinations in Bandung, it can be considered that the improvement of shopping tourism activities' supporting facilities and infrastructure is essential to achieve further improvements. It also supports the development of shopping tourism destination image in Bandung. Related to the tourists' overall satisfaction, the other exciting experiences are needed to meet the tourists' expectations in fulfilling their shopping tourism desires. The increase in the perception of destination image, and overall satisfaction through the achievement that even exceeding the tourists' expectations, the revisit intention of shopping destinations in Bandung will automatically increase. The sampling technique used in the study is a limitation on the representation of overall population characteristics, in addition to the other factors such as the researcher only focuses on related variables and based on shopping tourist destinations without relating with the other tourist destinations. Besides, the culture, habits, and characteristics of locus cannot be generalized to the other tourist destinations with different concepts and attributes or other possibilities.

\section{REFERENCES}

Ajzen, I. (2005). Attitudes, personality, and behavior. McGraw-Hill Education (UK).

Alegre, J., \& Garau, J. (2010). Tourist satisfaction and dissatisfaction. Annals of tourism research, 37(1), 52-73. https://doi.org/10.1016/j.annals.2009.07.001

Alexandris, K., Kouthouris, C., \& Meligdis, A. (2006). Increasing customers' loyalty in a skiing resort: The contribution of place attachment and service quality. International journal of contemporary hospitality management, 18(5), 414-425. https://doi.org/10.1108/09596110610673547

Allameh, S. M., Khazaei Pool, J., Jaberi, A., Salehzadeh, R., \& Asadi, H. (2015). Factors influencing sport tourists' revisit intentions: The role and effect of destination image, perceived quality, perceived value and satisfaction. Asia Pacific Journal of Marketing and Logistics, 27(2), 191-207. https://doi.org/10.1108/APJML-12-2013-0159 
Altintzoglou, T., Heide, M., \& Borch, T. (2016). Food souvenirs: buying behaviour of tourists in Norway. British Food Journal, 118(1), 119-131. https://doi.org/10.1108/BFJ-05-2015-0190

Andreasen, A. R. (1995). Marketing social change: Changing behavior to promote health, social development, and the environment (p. 101). San Francisco: Jossey-Bass.

ASEAN (2008) ASEAN Economic community blueprint http://asean.org/wpcontent/uploads/archive/5187-10.pdf

Bianchi, C., \& Pike, S. (2011). Antecedents of destination brand loyalty for a long-haul market: Australia's destination loyalty among Chilean travelers. Journal of Travel \& Tourism Marketing, 28(7), 736-750. https://doi.org/10.1080/10548408.2011.611742

Bolton, R. N., \& Drew, J. H. (1991). A longitudinal analysis of the impact of service changes on customer attitudes. Journal of marketing, 55(1), 1-9. https://doi.org/10.1177/002224299105500101

Campo-Martínez, S., Garau-Vadell, J. B., \& Martínez-Ruiz, M. P. (2010). Factors influencing repeat visits to a destination: The influence of group composition. Tourism Management, 31(6), 862-870. https://doi.org/10.1016/j.tourman.2009.08.013

Chen, C. F., \& Myagmarsuren, O. (2010). Exploring relationships between Mongolian destination brand equity, satisfaction and destination loyalty. Tourism Economics, 16(4), 981-994. https://doi.org/10.5367/te.2010.0004

Chen, C. F., \& Phou, S. (2013). A closer look at destination: Image, personality, relationship and loyalty. Tourism management, 36, 269-278. https://doi.org/10.1016/j.tourman.2012.11.015

Chen, C. M., Chen, S. H., \& Lee, H. T. (2011). The destination competitiveness of Kinmen's tourism industry: exploring the interrelationships between tourist perceptions, service performance, customer satisfaction and sustainable tourism. Journal of Sustainable Tourism, 19(2), 247-264. https://doi.org/10.1080/09669582.2010.517315

Cheng, T. M., \& Lu, C. C. (2013). Destination image, novelty, hedonics, perceived value, and revisiting behavioral intention for island tourism. Asia Pacific Journal of Tourism Research, 18(7), 766-783. https://doi.org/10.1080/10941665.2012.697906

Chew, E. Y. T., \& Jahari, S. A. (2014). Destination image as a mediator between perceived risks and revisit intention: A case of post-disaster Japan. Tourism Management, 40, 382-393. https://doi.org/10.1016/j.tourman.2013.07.008

Chi, C. G. Q., \& Qu, H. (2008). Examining the structural relationships of destination image, tourist satisfaction and destination loyalty: An integrated approach. Tourism management, 29(4), 624-636. https://doi.org/10.1016/j.tourman.2007.06.007 
Choi, J. G., Tkachenko, T., \& Sil, S. (2011). On the destination image of Korea by Russian tourists. Tourism Management, 32(1), 193-194. https://doi.org/10.1016/j.tourman.2009.12.002

Cronin Jr, J. J., \& Taylor, S. A. (1992). Measuring service quality: a reexamination and extension. Journal of marketing, 56(3), 55-68. https://doi.org/10.1177/002224299205600304

Donohue P, Power N (2014) Linking career anchors and social cognitive frameworks: developing an interview instrument. In: SIGSIM-CPR '14 Proceedings of the 52nd ACM conference on Computers and people research, Singapore, 29-31 May 2014. https://doi.org/10.1145/2599990.2600010

Fornell, C. (1992). A national customer satisfaction barometer: the Swedish experience. Journal of marketing, 56(1), 6-21. https://doi.org/10.1177/002224299205600103

Foster, B. (2018). Validation on Destination Image Attribute Towards Indonesian Tourist. Saudi Journal of Business and Management Studies, 3(6), 743-748. DOI:10.21276/sjbms.2018.3.6.20

Foster, B., \& Sidharta, I. (2019). A Perspective from Indonesian tourists: the influence of destination image on revisit intention. Journal of Applied Business Research (JABR), 35(1), 29-34.

Goddard, J., Molyneux, P., \& Wilson, J. O. (2004). Dynamics of growth and profitability in banking. Journal of Money, Credit and Banking, 1069-1090. https://doi.org/10.1353/mcb.2005.0015

Grönroos, C. (1984). A service quality model and its marketing implications. European Journal of marketing, 18(4), 36-44. https://doi.org/10.1108/EUM0000000004784

Gujarati DN (2003) Basic econometrics. 4th ed. New York: McGrawHill.

Gumanti TA (2000) Accounting information and the underpricing of Indonesian initial public offerings. PhD's Thesis, Australia: Edith Cowan University.

Hallmann, K., Zehrer, A., \& Müller, S. (2015). Perceived destination image: An image model for a winter sports destination and its effect on intention to revisit. Journal of Travel Research, 54(1), 94-106. https://doi.org/10.1177/0047287513513161

Hedge SP, Miller RE (1996) The informational role of debt and the pricing of initial public offerings. In: Levis $\mathrm{M}$ (Ed) Empirical issues in raising equity capital. Amsterdam: Elsevier, 151-174.

Hui, T. K., Wan, D., \& Ho, A. (2007). Tourists' satisfaction, recommendation and revisiting Singapore. Tourism management, 28(4), 965-975. https://doi.org/10.1016/j.tourman.2006.08.008

International Labour Organization (ILO) (2016) Labour overview of Latin America and the Caribbean. ILO, Lima. 
Josiassen, A., Assaf, A. G., Woo, L., \& Kock, F. (2016). The imagery-image duality model: an integrative review and advocating for improved delimitation of concepts. Journal of Travel Research, 55(6), 789-803. https://doi.org/10.1177/0047287515583358

Kock, N. (2014). Advanced mediating effects tests, multi-group analyses, and measurement model assessments in PLS-based SEM. International Journal of eCollaboration (IJeC), 10(1), 1-13. DOI: 10.4018/ijec.2014010101

Kim, S. H., Holland, S., \& Han, H. S. (2013). A structural model for examining how destination image, perceived value, and service quality affect destination loyalty: A case study of Orlando. International Journal of Tourism Research, 15(4), 313-328. https://doi.org/10.1002/jtr.1877

Kim, H. B., \& Lee, S. (2015). Impacts of city personality and image on revisit intention. International Journal of Tourism Cities, 1(1), 50-69. https://doi.org/10.1108/IJTC-082014-0004

Kong, W. H., \& Chang, T. Z. (2012). The role of souvenir shopping in a diversified Macau destination portfolio. Journal of Hospitality Marketing \& Management, 21(4), 357-373. https://doi.org/10.1080/19368623.2011.615022

Kong, W. H., \& Chang, T. Z. (2016). Souvenir shopping, tourist motivation, and travel experience. Journal of Quality Assurance in Hospitality \& Tourism, 17(2), 163-177. https://doi.org/10.1080/1528008X.2015.1115242

Kozak, M., \& Rimmington, M. (2000). Tourist satisfaction with Mallorca, Spain, as an off-season holiday destination. Journal of travel research, 38(3), 260-269. https://doi.org/10.1177/004728750003800308

Lanine G, Vennet RV (2005) Failure prediction in the Russian bank sector with logit and trait recognition models: Working paper. Ghent University, Belgium.

Lehto, X. Y., Cai, L. A., O’Leary, J. T., \& Huan, T. C. (2004). Tourist shopping preferences and expenditure behaviours: The case of the Taiwanese outbound market. Journal of Vacation Marketing, 10(4), 320-332. https://doi.org/10.1177/135676670401000404

LeHew, M. L., \& Wesley, S. C. (2007). Tourist shoppers' satisfaction with regional shopping mall experiences. International Journal of Culture, Tourism and Hospitality Research, 1(1), 82-96. https://doi.org/10.1108/17506180710729628

Lin, L., \& Mao, P. C. (2015). Food for memories and culture-A content analysis study of food specialties and souvenirs. Journal of Hospitality and Tourism Management, 22, 19-29. https://doi.org/10.1016/j.jhtm.2014.12.001

Loi, L. T. I., So, A. S. I., Lo, I. S., \& Fong, L. H. N. (2017). Does the quality of tourist shuttles influence revisit intention through destination image and satisfaction? The case of Macao. Journal of Hospitality and Tourism Management, 32, 115-123. https://doi.org/10.1016/j.jhtm.2017.06.002 
Makkonen, T. (2016). Cross-border shopping and tourism destination marketing: the case of Southern Jutland, Denmark. Scandinavian journal of hospitality and tourism, 16(sup1), 36-50. https://doi.org/10.1080/15022250.2016.1244506

McKercher, B., \& Wong, D. Y. (2004). Understanding tourism behavior: Examining the combined effects of prior visitation history and destination status. Journal of Travel Research, 43(2), 171-179. https://doi.org/10.1177/0047287504268246

Mechinda, P., Serirat, S., \& Gulid, N. (2009). An examination of tourists' attitudinal and behavioral loyalty: Comparison between domestic and international tourists. Journal of vacation marketing, 15(2), 129-148. https://doi.org/10.1177/1356766708100820

Morais, D. B., \& Lin, C. H. (2010). Why do first-time and repeat visitors patronize a destination?. Journal of Travel \& Tourism Marketing, 27(2), 193-210. https://doi.org/10.1080/10548401003590443

Oliver, R. L. (1993). Cognitive, affective, and attribute bases of the satisfaction response. Journal of consumer research, 20(3), 418-430. https://doi.org/10.1086/209358

Papadimitriou, D., Apostolopoulou, A., \& Kaplanidou, K. (2015). Destination personality, affective image, and behavioral intentions in domestic urban tourism. Journal of Travel Research, 54(3), 302-315. https://doi.org/10.1177/0047287513516389

Parasuraman, A., Zeithaml, V. A., \& Berry, L. L. (1985). A conceptual model of service quality and its implications for future research. Journal of marketing, 49(4), 41-50. https://doi.org/10.1177/002224298504900403

Prayag, G. (2009). Tourists'evaluations of destination image, satisfaction, and future behavioral intentions - the case of mauritius. Journal of Travel \& Tourism Marketing, 26(8), 836-853. https://doi.org/10.1080/10548400903358729

Prayag, G., Hosany, S., Muskat, B., \& Del Chiappa, G. (2017). Understanding the relationships between tourists' emotional experiences, perceived overall image, satisfaction, and intention to recommend. Journal of Travel Research, 56(1), 41-54. https://doi.org/10.1177/0047287515620567

Qu, H., Kim, L. H., \& Im, H. H. (2011). A model of destination branding: Integrating the concepts of the branding and destination image. Tourism management, 32(3), 465476. https://doi.org/10.1016/j.tourman.2010.03.014

Ramkissoon, H., Uysal, M., \& Brown, K. (2011). Relationship between destination image and behavioral intentions of tourists to consume cultural attractions. Journal of Hospitality Marketing \& Management, 20(5), 575-595. https://doi.org/10.1080/19368623.2011.570648

Ramseook-Munhurrun, P., Seebaluck, V. N., \& Naidoo, P. (2015). Examining the structural relationships of destination image, perceived value, tourist satisfaction and loyalty: case of Mauritius. Procedia-Social and Behavioral Sciences, 175, 252-259. https://doi.org/10.1016/j.sbspro.2015.01.1198 
Stylos, N., Vassiliadis, C. A., Bellou, V., \& Andronikidis, A. (2016). Destination images, holistic images and personal normative beliefs: Predictors of intention to revisit a destination. Tourism Management, 53, 40-60. https://doi.org/10.1016/j.tourman.2015.09.006

Stylos, N., Bellou, V., Andronikidis, A., \& Vassiliadis, C. A. (2017). Linking the dots among destination images, place attachment, and revisit intentions: A study among British and Russian tourists. Tourism Management, 60, 15-29. https://doi.org/10.1016/j.tourman.2016.11.006

Swanson, K. K., \& Horridge, P. E. (2006). Travel motivations as souvenir purchase indicators. Tourism management, 27(4), 671-683. https://doi.org/10.1016/j.tourman.2005.03.001

Tian-Cole, S., \& Cromption, J. (2003). A conceptualization of the relationships between service quality and visitor satisfaction, and their links to destination selection. Leisure studies, 22(1), 65-80. https://doi.org/10.1080/02614360306572

Tosun, C., Dedeoğlu, B. B., \& Fyall, A. (2015). Destination service quality, affective image and revisit intention: The moderating role of past experience. Journal of Destination Marketing \& Management, 4(4), 222-234. https://doi.org/10.1016/j.jdmm.2015.08.002

Tosun, C., Temizkan, S. P., Timothy, D. J., \& Fyall, A. (2007). Tourist shopping experiences and satisfaction. International Journal of Tourism Research, 9(2), 87-102. https://doi.org/10.1002/jtr.595

Um, S., Chon, K., \& Ro, Y. (2006). Antecedents of revisit intention. Annals of tourism research, 33(4), 1141-1158. https://doi.org/10.1016/j.annals.2006.06.003

Wang, C. Y., \& Hsu, M. K. (2010). The relationships of destination image, satisfaction, and behavioral intentions: An integrated model. Journal of Travel \& Tourism Marketing, 27(8), 829-843. https://doi.org/10.1080/10548408.2010.527249

Weiermair, K. (2000). Tourists' perceptions towards and satisfaction with service quality in the cross-cultural service encounter: implications for hospitality and tourism management. Managing Service Quality: An International Journal, 10(6), 397-409. https://doi.org/10.1108/09604520010351220

Wijaya, S., King, B., Morrison, A., \& Nguyen, T. H. (2017). Destination encounters with local food: The experience of international visitors in Indonesia. Tourism Culture \& Communication, 17(2), 79-91. https://doi.org/10.3727/109830417X14966810027526 